
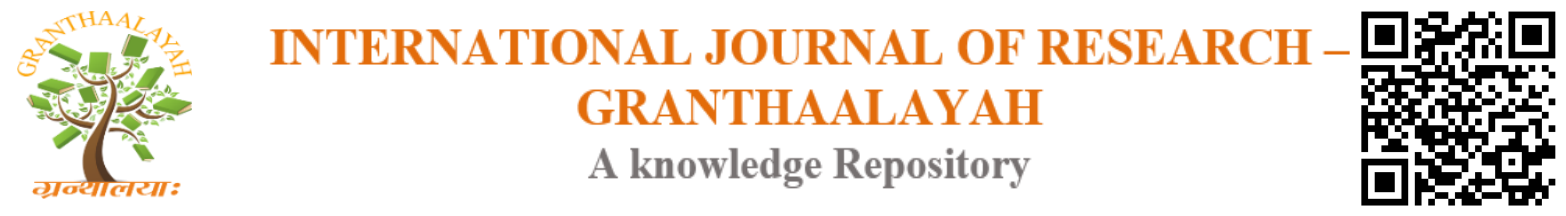

Management

\title{
ORGANIZATIONAL CAPACITY ASSESSMENT AS INPUT TO POLICY DIRECTION IN THE UNIVERSITY OF EASTERN PHILIPPINES, CATARMAN NORTHERN SAMAR
}

\author{
Felisa P. Lucero-Sanico ${ }^{1,2}$ \\ ${ }^{1}$ Vice President for Academic Affairs and a Faculty member of the College of Education, \\ University of Eastern Philippines, University Town, Catarman N. Samar \\ ${ }^{2}$ Research Office, University of Eastern Philippines, University Town, Catarman N. Samar
}

\begin{abstract}
This study focused on the organizational capacity assessment of the University of Eastern Philippines as an input to policy direction. This employed descriptive research design using the middle level management of every college covering the Deans and department chairs as respondents. This included the members of the University Administrative Council. OCA assessment template was modified and used as instrument of this study.

This study found out that mostly of the middle managers are older, female, and a majority of the middle managers are younger in the service which signifies that the institution is after the fresh ideas of newer in the service. The university were assessed in the seven (7) capacity areas: governance, operations and management, human resources development, financial management, business services, delivery, communication (vertical and horizontal), and external relations. The middle managers are consistent with their responses on their capacity along business services delivery, financial management, and human resource development.

Along the recommendatory assessment, the University should focus on assessing the governing body whether it functions and attracts funding, review regularly and update the University Code, benchmark effective strategy for implementing business plans for IGPs, facilities and equipment management control in place, develop and follow staff training plan, prepare system to motivate staff in place, follow budgetary allocation seriously, determine adequate capacity for bulking of inputs and agricultural products, use of assessment tools for evaluating members satisfaction with services provided to them, improve capacity to set baselines, targets and monitor, meet local market share adequately, improve grievance mechanism, establish e-communication platform, in place faculty and student exchange program, and mainstream the alumni to the university activities.
\end{abstract}

Keywords: Organizational Capacity Assessment; Policy-Direction; Educational Management.

Cite This Article: Felisa P. Lucero-Sanico. (2019). "ORGANIZATIONAL CAPACITY ASSESSMENT AS INPUT TO POLICY DIRECTION IN THE UNIVERSITY OF EASTERN PHILIPPINES, CATARMAN NORTHERN SAMAR." International Journal of Research - Granthaalayah, 7(3), 120-129. https://doi.org/10.29121/granthaalayah.v7.i3.2019.951. 


\section{Introduction}

Every organization must be aware of its capability through its strengths, weaknesses and values in order to effectively serve its clientele. An organizational assessment review has to be periodically conducted to attune the direction and operational management of the different organizational units. The transition of the university governance necessitates revising of its organizational management in improving if not revising some of the policies and development direction of the university. Capacity as conceptually defined based on the findings of Christensen and Gazley (2008), as the ability of an organization to fulfill its goals and researches focused on determining the variables that impact organizational performance. In the case of the present study, organizational capacity was assessed for policy direction. In the study of Gargan (1980:652) as cited by Bryan (2011), it was defined as the ability of an organization "to do what it wants to do." This was studied in the paper of Bryan (2011). Utilizing a two-phase sequential mixed method design through interview and survey, the study of Bryan (2011) found out that organizational capacity consisted of a number organizational resources and capabilities that impact the functioning of the internal organization as well as its relationships with other relevant organizations and external stakeholder; six dimensions of capacity were identified: human resource, financial resource, information technology, knowledge, stakeholder commitment, and collaborative. The findings highlighted on six dimensions which are connected to the theoretical construct of organizational capacity. However, results from the discriminant validity tests of the six subscales are mixed. Mustapa et al (2014:76-83) found out that company needs to have adequate infrastructure and utilize it appropriately because its interaction with corporate governance is proven to have an influence on corporate performance. Findings of this research recognize that infrastructure emerges as an important element to the research of corporate governance.

Two dimensions of organizational capacity positively affect the firm innovative performance: system orientation and knowledge acquisition-utilization orientation (Comlek, (2012). This is further confirmed by the findings of Kitapci and Celik (2014) that firms can enhance quality performance through improving organizational learning capacity. This is also true with Tayles et al (2007) that strategy is a pattern of allocating resources that allows a company to maintain and improve performance generating fitness among a company's activities.

The result of this study is significantly important as input in mainstreaming and revising some policy issues as input in the transformational focus of the major mandated functions of the university. This study focused on the organizational capacity assessment of the University of Eastern Philippines as an input to policy direction.

\section{Methodology}

This study employed descriptive research design. It made use of the middle level management as respondents. OCA assessment template was modified and used as instrument of this study.

In assessing the university in the seven (7) capacity areas: governance, operations and management, human resources development, financial management, business services, delivery, communication (vertical and horizontal), and external relations, the following scoring were used: 


\begin{tabular}{|l|l|}
\hline Scores & Description \\
\hline 5 & Excellent achievement, capacity fully achieved \\
\hline 4 & No need for immediate improvement \\
\hline 3 & Some progress made only little improvement required \\
\hline 2 & Needs improvement \\
\hline 1 & Neutral, no improvement made \\
\hline 0 & Non-existent \\
\hline
\end{tabular}

In determining the level of organizational capability of along the seven (7) areas, the following interpretation was used:

\begin{tabular}{|l|l|}
\hline Weighted Mean & Level of Capability \\
\hline $4.00-5.00$ & Very highly capable \\
\hline $3.00-3.99$ & Highly capable \\
\hline $2.00-2.99$ & Capable \\
\hline $1.00-0.99$ & Poorly capable \\
\hline $0-0.99$ & Not capable \\
\hline
\end{tabular}

\section{Results and Discussion}

\section{Profile of the Respondents}

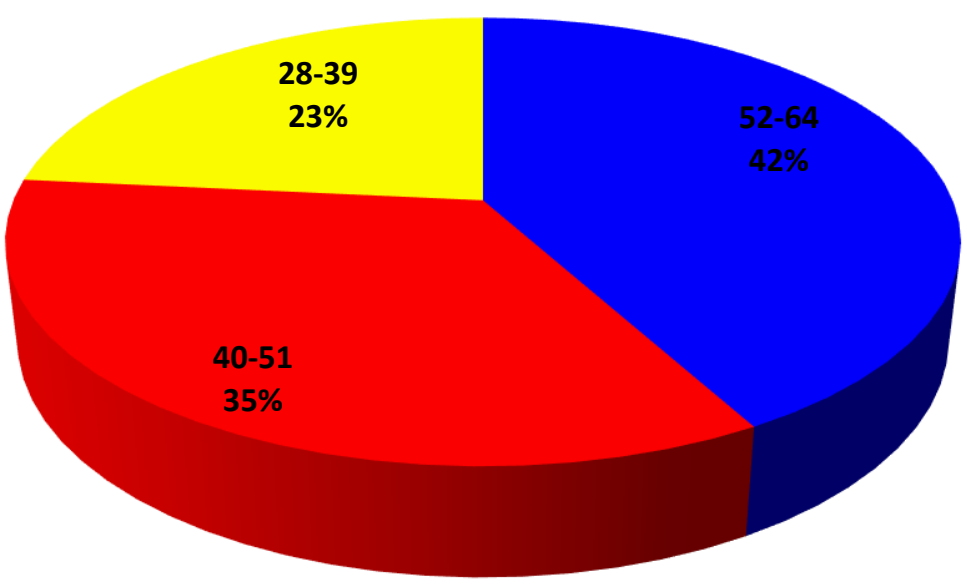

Figure 1. Profile of the Middle Managers according to Age.

Figure 1: presents the profile of the middle managers according to age. It shows that 19 middle managers or 23 percent are within the age bracket of 28-39, 28 or 35 percent are within 40-51 age bracket and 34 or 42 percent are within 52-64 age bracket. This means that mostly of the middle managers are older compared to the rest of the middle managers considering the bountiful experiences along the journey of becoming middle managers. 


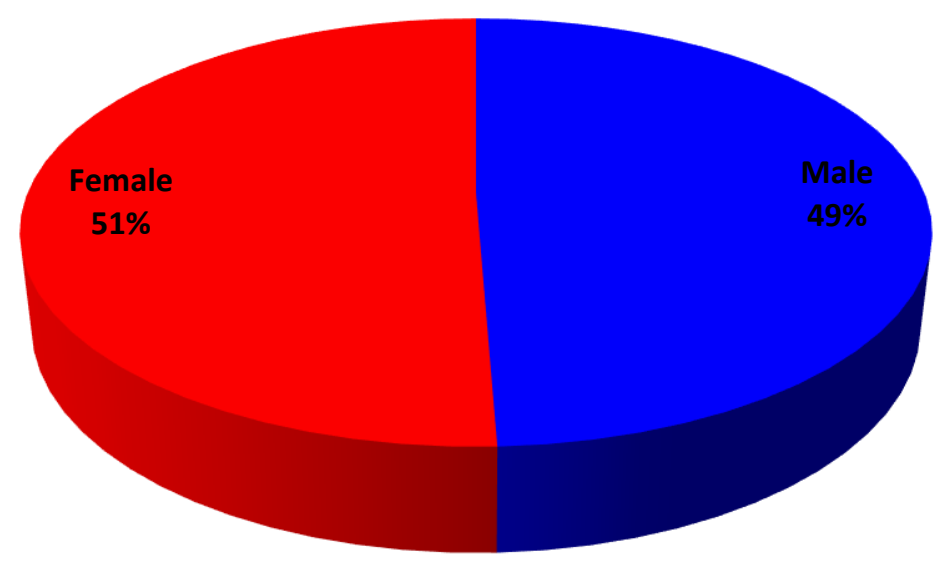

Figure 2. Profile of the Middle Managers according to Gender.

Figure 2: shows the profile of the middle managers in terms of gender. It presents that 40 or 49 percent are male and 41 or 51 percent are female. It means that mostly of the middle managers are female.

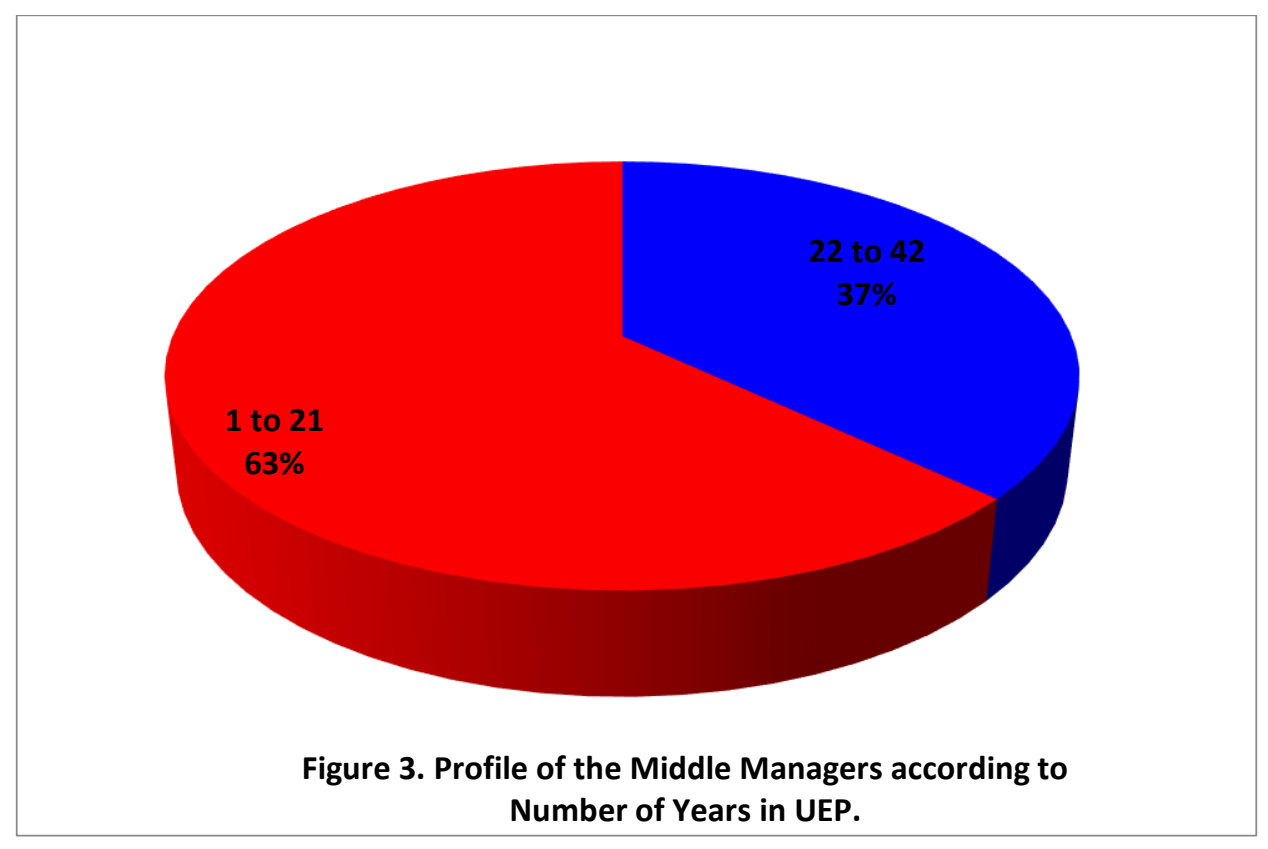

Figure 3: presents the profile of the middle managers according to number of years in UEP. It shows that 51 or 63 percent are within 1-21 years in UEP and 30 or 37 percent are within 22-42 years in UEP. This means that a majority of the middle managers are younger in the service which signifies that the institution is after the fresh ideas of newer in the service.

\section{Assessment of Organizational Capacity along Governance}

It is presented in Table 1 on governance that the university with a mean of 3.93 which is interpreted as "highly capable." Specifically, the university is very highly capable along the following items: 
mission statement of the university with a business orientation clearly articulated (4.02), legal status compliant with official registration requirements (4.08), and democratic elections held (4.23). This means that the University along governance is competent in explicitly incorporating business orientation on its mission statement, complying legal requirements in its SEC registration and adhering to democracy in its elections.

Table 1: Organizational Capacity along Governance

\begin{tabular}{|l|l|l|}
\hline Capacity Areas along Governance & $\begin{array}{l}\text { Weighted } \\
\text { Mean }\end{array}$ & Interpretation \\
\hline Governing body functioning and attracting funding & 3.67 & highly capable \\
\hline Governing board providing leadership & 3.98 & highly capable \\
\hline $\begin{array}{l}\text { Mission statement of the university with a business orientation } \\
\text { clearly articulated }\end{array}$ & 4.02 & very highly capable \\
\hline Legal status compliant with official registration requirements & 4.08 & very highly capable \\
\hline Differentiation of oversight and management roles followed & 3.84 & highly capable \\
\hline $\begin{array}{l}\text { General membership is represented adequately in all leadership } \\
\text { and governance structures }\end{array}$ & 3.91 & highly capable \\
\hline Gender balance and representations exists & 3.97 & highly capable \\
\hline Democratic elections held & 4.23 & very highly capable \\
\hline $\begin{array}{l}\text { Constitution and by-laws/university code reviewed regularly } \\
\text { and updated }\end{array}$ & 3.60 & highly capable \\
\hline Empowers everyone to be responsible in his/her action & 4.00 & very highly capable \\
\hline & $\mathbf{3 . 9 3}$ & highly capable \\
\hline
\end{tabular}

\section{Assessment of Organizational Capacity along Operations and Management}

In the area of operations and management as shown in Table 2.2, with a mean of 3.67, the university is highly capable. Specifically, the university is highly capable in the following areas: participative planning process is practiced (3.86), monitoring and evaluation of activities is in place (3.78), and operations manuals are established (3.71). This implies that the university is competent in practicing participative planning process, implementing monitoring and evaluation and establishing operations manual.

Table 2: Organizational Capacity along Operations and Management

\begin{tabular}{|l|l|l|}
\hline Operations and Management & $\begin{array}{l}\text { Weighted } \\
\text { Mean }\end{array}$ & Interpretation \\
\hline Operations manuals are established policies & 3.71 & highly capable \\
\hline $\begin{array}{l}\text { Standard operating procedures and } \\
\text { functioning }\end{array}$ & 3.69 & highly capable \\
\hline Participative planning process is practiced & 3.60 & highly capable \\
\hline Effective use of information tools and systems & 3.48 & highly capable \\
\hline $\begin{array}{l}\text { Effective strategy for implementing business plans for } \\
\text { IGPs }\end{array}$ & 3.53 & highly capable \\
\hline Facilities and equipment management control in place \\
\hline $\begin{array}{l}\text { Capacity for developing business plans aligned with } \\
\text { vision and mission }\end{array}$ & 3.62 & highly capable \\
\hline
\end{tabular}


DOI: 10.5281/zenodo.2619432

\begin{tabular}{|l|l|l|}
\hline $\begin{array}{l}\text { Transparent process for decision making in regular } \\
\text { use }\end{array}$ & 3.69 & highly capable \\
\hline Performance audit is regularly conducted & 3.68 & highly capable \\
\hline Monitoring and evaluation of activities is in place & 3.78 & highly capable \\
\hline & $\mathbf{3 . 6 7}$ & highly capable \\
\hline
\end{tabular}

\section{Human Resource Development}

As presented in Table 3 along human resource development, the university is highly capable. Specifically, the university is highly capable in the following areas: staff has appropriate numbers to achieve the mission of the organization (3.70), staff has appropriate skills to achieve the mission of the organization (3.70), and every staff member has a clear work plan for meeting the strategy of the organization (3.69).

Table 3: Organizational Capacity along Human Resource Development

\begin{tabular}{|l|l|l|}
\hline Human Resource Development & $\begin{array}{l}\text { Weighted } \\
\text { Mean }\end{array}$ & Interpretation \\
\hline Systems training plan developed and being followed & 3.54 & highly capable \\
\hline $\begin{array}{l}\text { Transparent merit-based recruitment procedure in } \\
\text { place }\end{array}$ & 3.47 & highly capable \\
\hline Systems to motivate staff in place & 3.52 & highly capable \\
\hline $\begin{array}{l}\text { Systems for compensation and staff benefits } \\
\text { developed and being followed }\end{array}$ & 3.59 & highly capable \\
\hline Staff training plan developed and being followed & 3.50 & highly capable \\
\hline Staff know why they do what they are doing & 3.63 & highly capable \\
\hline $\begin{array}{l}\text { Every staff member has a clear work plan for } \\
\text { meeting the strategy of the organization }\end{array}$ & 3.69 & highly capable \\
\hline $\begin{array}{l}\text { Staff hold regular meetings to review and affirm the } \\
\text { strategy }\end{array}$ & 3.64 & highly capable \\
\hline $\begin{array}{l}\text { Staff have appropriate skills to achieve the mission } \\
\text { of the organization }\end{array}$ & 3.70 & highly capable \\
\hline $\begin{array}{l}\text { Staff have appropriate numbers to achieve the } \\
\text { mission of the organization }\end{array}$ & 3.70 & highly capable \\
\hline & $\mathbf{3 . 6 0}$ & highly capable \\
\hline
\end{tabular}

\section{Financial Management}

In the area of financial management, the university is highly capable as shown in Table 4. Specifically, the university is highly capable in the following areas: existence of updated accounting policies, procedures, and manuals (3.90), books of account are current (3.90), and internal controls adhered to (3.90).

Table 4: Organizational Capacity along Financial Management

\begin{tabular}{|l|l|l|}
\hline Financial Management & $\begin{array}{l}\text { Weighted } \\
\text { Mean }\end{array}$ & Interpretation \\
\hline Books of account are current & 3.90 & highly capable \\
\hline $\begin{array}{l}\text { Existence of updated accounting policies, } \\
\text { procedures, and manuals. }\end{array}$ & 3.90 & highly capable \\
\hline
\end{tabular}


DOI: 10.5281/zenodo.2619432

\begin{tabular}{|l|l|l|}
\hline Transparent budgeting process operational & 3.89 & highly capable \\
\hline Internal controls adhered to & 3.90 & highly capable \\
\hline $\begin{array}{l}\text { Internal and external audits/financial reviews } \\
\text { undertaken regularly }\end{array}$ & 3.88 & highly capable \\
\hline Diverse and sustainable resource base exist & 3.76 & highly capable \\
\hline $\begin{array}{l}\text { Member involved in budget preparation and } \\
\text { approval }\end{array}$ & 3.84 & highly capable \\
\hline Financial records regularly available to members & 3.74 & highly capable \\
\hline Budgetary allocation is seriously followed & 3.66 & highly capable \\
\hline Prioritization of project expenditure is observed & 3.79 & highly capable \\
\hline & $\mathbf{3 . 8 2}$ & highly capable \\
\hline
\end{tabular}

\section{Business Services Delivery}

As shown in Table 5 below on business services delivery, the university is highly capable. Specifically, the university is highly capable in the following areas: support services provided by financial units (3.58), rationalize the operation of IGPs (3.57), and business friendly attitude provided by personnel (3.57).

Table 5: Organizational Capacity along Business Services Delivery

\begin{tabular}{|l|l|l|}
\hline Business Services Delivery & $\begin{array}{l}\text { Weighted } \\
\text { Mean }\end{array}$ & Interpretation \\
\hline Rationalize the operation of IGPs & 3.57 & highly capable \\
\hline $\begin{array}{l}\text { Adequate capacity for bulking of inputs and } \\
\text { agricultural products }\end{array}$ & 3.44 & highly capable \\
\hline $\begin{array}{l}\text { Use of assessment tools for evaluating members } \\
\text { satisfaction with services provided to them }\end{array}$ & 3.37 & highly capable \\
\hline $\begin{array}{l}\text { Capacity to set baselines, targets and monitor } \\
\text { improvements }\end{array}$ & 3.44 & highly capable \\
\hline Capacity to identify appropriate business services & 3.49 & highly capable \\
\hline $\begin{array}{l}\text { Demonstrated capacity to sustain market-driven } \\
\text { business services }\end{array}$ & 3.51 & highly capable \\
\hline Support services provided by financial units & 3.58 & highly capable \\
\hline Local market share is adequately met & 3.43 & highly capable \\
\hline Other value-added services are provided & 3.50 & highly capable \\
\hline Business friendly attitude provided by personnel & 3.57 & highly capable \\
\hline & $\mathbf{3 . 4 9}$ & highly capable \\
\hline
\end{tabular}

\section{Communication}

In the area of communication as presented on Table 6, the university is highly capable. Specifically, the university is very highly capable in the following areas: academic and administrative units regularly hold meetings (4.10), participative mood is observable in all meeting (4.02), and communication protocol being followed in official transaction/ matters with the university (4.01). 
Table 6: Organizational Capacity along Communication

\begin{tabular}{|c|c|c|}
\hline Communication & $\begin{array}{l}\text { Weighted } \\
\text { Mean }\end{array}$ & Interpretation \\
\hline Communication manual and protocol is in place & 3.67 & highly capable \\
\hline Grievance mechanism is in place & 3.59 & highly capable \\
\hline $\begin{array}{l}\text { Observance of inter-college/inter-departmental or open } \\
\text { communication }\end{array}$ & 3.85 & highly capable \\
\hline Academic and administrative units regularly hold meetings & 4.10 & very highly capable \\
\hline Participative mood is observable in all meetings & 4.02 & very highly capable \\
\hline $\begin{array}{l}\text { Communication protocol being followed in official } \\
\text { transaction/ matters with the university }\end{array}$ & 4.01 & very highly capable \\
\hline Print and broadcast media are in place & 3.86 & \\
\hline $\begin{array}{l}\text { University communication clearing house is in pale and } \\
\text { functional }\end{array}$ & 3.67 & highly capable \\
\hline Innovative ideas are recognized and rewarded & 3.89 & highly capable \\
\hline \multirow[t]{2}{*}{ e-communication platform is established. } & 3.59 & highly capable \\
\hline & 3.83 & highly capable \\
\hline
\end{tabular}

\section{External Relations}

As presented in the Table 7 below on external relations, the university is highly capable. Specifically, the university is highly capable along the following areas: formal working relationships with government agencies in place (3.97), business partnerships with private sector is in place (3.93), and written agreement with private sector and NGOs in place (3.88).

Table 7: Organizational Capacity along External Relations

\begin{tabular}{|l|l|l|}
\hline External Relations & $\begin{array}{l}\text { Weighted } \\
\text { Mean }\end{array}$ & Interpretation \\
\hline Forged academic partnership with foreign HEIs & 3.77 & highly capable \\
\hline $\begin{array}{l}\text { Established academic and research partnership with regional and } \\
\text { national and international HEIs }\end{array}$ & 3.86 & highly capable \\
\hline Formal working relationships with government agencies in place & 3.97 & highly capable \\
\hline Written agreement with private sector and NGOs in place & 3.88 & highly capable \\
\hline Partnership with industry in place & 3.87 & highly capable \\
\hline Advocacy strategy being implemented & 3.89 & highly capable \\
\hline Business partnerships with private sector is in place & 3.93 & highly capable \\
\hline $\begin{array}{l}\text { Strategic working partnerships in place to develop a social } \\
\text { responsibility charter }\end{array}$ & 3.80 & highly capable \\
\hline Faculty and student exchange program in place & 3.65 & highly capable \\
\hline Mainstream the alumni to the university activities & 3.58 & highly capable \\
\hline & $\mathbf{3 . 8 2}$ & highly capable \\
\hline
\end{tabular}

\section{Variability of the Organizational Capacity of the University}

In the table below (Table 8), it could be gleaned that the capacity areas with high acceptability through its standard deviation includes: business services delivery $(\sigma=0.07)$, financial management $(\sigma=0.08)$, communication $(\sigma=0.08)$ and human resource development $(\sigma=0.09)$. This means that 
along the different capacity areas, the middle managers in UEP agree with each other in their responses along business services delivery, financial management, and human resource development. This further means that the University is competent along support services provided by financial units, rationalize the operation of IGPs, and business friendly attitude provided by personnel. There is an existence of updated accounting policies, procedures, and manuals, books of account are current, and internal controls adhered to. It is implied that academic and administrative units regularly hold meetings, participative mood is observable in all meeting, and communication protocol being followed in official transaction/ matters with the university. Staff has appropriate numbers to achieve the mission of the organization, staff has appropriate skills to achieve the mission of the organization, and every staff member has a clear work plan for meeting the strategy of the organization.

Table 8: Level of Variability of the Organizational Capacity of the University

\begin{tabular}{|l|l|l|l|}
\hline Capacity Areas & $\bar{x}$ & $\sigma$ & Interpretation \\
\hline Governance & 3.93 & 0.19 & Acceptable \\
\hline Operations and Management & 3.67 & 0.11 & Acceptable \\
\hline Human Resource Development & 3.60 & 0.09 & Acceptable \\
\hline Financial Management & 3.82 & 0.08 & Acceptable \\
\hline Business Services Delivery & 3.49 & 0.07 & Acceptable \\
\hline Communication & 3.82 & 0.08 & Acceptable \\
\hline External Relations & 3.82 & 0.12 & Acceptable \\
\hline
\end{tabular}

$\sigma<0.10$ means high acceptable

\section{Recommendatory Assessment of the Organizational Capacity}

Based on the results of the different capacity areas, the University should focus on assessing the governing body whether it functions and attracts funding, review regularly and update the University Code, benchmark effective strategy for implementing business plans for IGPs, facilities and equipment management control in place, develop and follow staff training plan, prepare system to motivate staff in place, follow budgetary allocation seriously, determine adequate capacity for bulking of inputs and agricultural products, use of assessment tools for evaluating members satisfaction with services provided to them, improve capacity to set baselines, targets and monitor, meet local market share adequately, improve grievance mechanism, establish ecommunication platform, in place faculty and student exchange program, and mainstream the alumni to the university activities.

\section{Conclusions}

This study found out that mostly of the middle managers are older compared to the rest of the middle managers considering the bountiful experiences along the journey of becoming middle managers, female, and a majority of the middle managers are younger in the service which signifies that the institution is after the fresh ideas of newer in the service.

In assessing the organizational capacity, it found out that the university is very highly capable along governance by clearly articulating mission statement of the university with a business orientation, complying legal status with official registration requirements, and holding democratic 
elections. Along operations and management, UEP is capable in practicing participative planning process, in placing monitoring and evaluation of activities, and establishing operations manuals. Under human resource development, the university is highly capable in providing appropriate number of staff in achieving the mission of the organization, developing skills of staff appropriate in achieving the mission of the organization, and identifying clear work plan of every staff member in meeting the strategy of the organization. In the area of financial management, the university is highly capable in providing updated accounting policies, procedures, and manuals, updating books of account, and adhering to internal controls. On business services delivery, the university is highly capable in providing support services by financial units, rationalizing the operation of IGPs, and providing business friendly attitude. In the area of communication, the university is highly capable in regularly holding meetings academic and administrative units, observing participative mood in all meetings, and following communication protocol in official transaction/ matters with the university. And on external relations, the university is highly capable in placing the formal working relationships with government agencies, business partnerships with private sector, and written agreement with private sector and NGOs. The middle managers are consistent with their responses on their capacity along business services delivery, financial management, and human resource development.

Along the recommendatory assessment, the University should focus on assessing the governing body whether it functions and attracts funding, review regularly and update the University Code, benchmark effective strategy for implementing business plans for IGPs, facilities and equipment management control in place, develop and follow staff training plan, prepare system to motivate staff in place, follow budgetary allocation seriously, determine adequate capacity for bulking of inputs and agricultural products, use of assessment tools for evaluating members satisfaction with services provided to them, improve capacity to set baselines, targets and monitor, meet local market share adequately, improve grievance mechanism, establish e-communication platform, in place faculty and student exchange program, and mainstream the alumni to the university activities.

\section{References}

[1] Bryan, T.K. (2011). Exploring the Dimensions of Organizational Capacity for Local Social Service Delivery Organizations Using a Multi-Method Approach. Unpublished Dissertation. Virginia Polytechnic Institute and State University, p.2.

[2] Kitapci, H. \& Celik, V. (2014). The Relationship between Ambidexterity, Organizational Learning Capacity and Firm Quality Performance: An Empirical Study. Procedia - Social and Behavioral Science, Volume109.

[3] Mustapa, I.R., Ghazali, N.A.M., Mohamad, M.H.S. (2014). The moderating influence of organizational capacity on the association between coprotate governance and corporate performance. International Conference on Accounting Studies 2014. Science Direct Volume 164.

[4] Tayles, M., Pike, R.H. \& Sofian, S. (2007). Intellectual capital, management accounting practices and corporate performance: perception of managers. Accounting, Auditing and Accountability Journal, Volume 20 (4). 